REVIEW ARTICLE

\title{
Little Truth and No Understanding
}

$\mathrm{BY}$

\section{J. DINGLEY}

Loftus, John. The Belarus Secret, Alfred A. Knopf, New York, 1982. 196 pages. (British edition: Penguin Books, Harmondsworth, 1983). (All page references are to the American edition).

This book contains two major thrusts of attack. The first of them is contained in the accusation that Byelorussians were active in collaborating with the German occupiers of their country in 1941-44, especially in committing atrocities; the second is that certain US intelligence agencies, especially Frank Wisner's Office of Policy Coordination (OPC), smuggled known Byelorussian Nazi war criminals into the USA in defiance of American law and without informing the President or Congress. The seriousness of the second accusation is compounded by Loftus' assertion that Wisner was tricked by his smuggled war criminals into believing that a spy network could be set up in Soviet-occupied Europe.

The author is a young (34) lawyer of Irish Catholic extraction from Boston. The material for the book was gathered in two and a half years spent as a federal prosecutor (so he describes himself in the preface) in the Office of Special Investigations (OSI) of the Criminal Division of the Justice Department (the 'Nazi war crimes unit'); his particular function, again according to the preface, was 'Coordinator of a highly classified inquiry called the Belarus Project'. His superior at the OSI, however, describes him in rather humbler terms. In an interview with Charles R. Allen ('Give me your tired, your poor. . your Nazi war criminals', The Jewish Veteran, vol.37, no.1, Sept.-October 1982, p.10), Allan A. Ryan denied that Loftus ever prosecuted Nazi war criminal cases while with OSI, saying that he 'did legal research for our trial attorneys'.

The conclusions of the book 'are based primarily upon available public records', but it should be stressed right at the outset that Loftus attaches considerable importance to two documents that are beyond the reach of the ordinary reader, or even academic researcher, because they remain classified. The first is the manuscript memoirs of a concentration camp inmate, Solomon Schiadow, and the second the memoirs of Friedrich Buchardt, who had served in Vorkommando Moskau of Einsatzkommando B under Standartenführer Prof. Franz Six. The book under review provides no illustration of either of these secret 
documents. The book has the apparatus of scholarly research - footnotes and copious textual notes - but there is no separate bibliography, and the illustrations have all been previously published. Throughout the necessary research the author was assisted by persons who, unlike him, were perhaps able to read the languages other than English necessary for the job.

I cannot hope, within the scope of this review, to deal with the sections of the book which refer to the American Secret Services, and it would be impertinent to attempt to do more than recount the thrust of Loftus' argument in this area. On the other hand a close examination of the book reveals so many errors and illogicalities in other areas as to call into question the validity of any of the author's conclusions.

Loftus is obviously a monoglot without any precise knowledge of the recent history of a people on which he pronounces judgement. In particular he obviously does not really understand the historical position of Byelorussia, and the claims of Poles and Russians to dominance over the country. This must cast some doubt over his approach; indeed this doubt is intensified when it becomes clear that Loftus has employed a research methodology that smacks of the world of spy fiction, e.g. employing an agent provocateur, one Marc Mazurovsky (if that is his real name), to pose as a researcher to gain access to the homes of Byelorussians in America; climbing over walls at dead of night to gain access to a cemetery which is, in any case, open during the day (as Loftus discovers on p.6). The style of writing also betrays a duality of purpose: at one moment serious and dry, at another emotionally coloured in the manner of cheap thrillers, e.g. the 'compounding-of-adjectives' method in the description of St. Stankievic as 'obese and jowly', or the 'superflous-detail-to-add-colour' method when we are told that Wisner contracted hepatitis from eating tainted clams in Athens.

It is, however, at the level of serious statement that the book's shortcomings reveal themselves. Loftus' ignorance of Byelorussian history betrays itself in such gross errors as dating the 'merger' between the BNR and the BSSR in 1930, or calling Byelorussians in Poland (p.15) 'émigrés'. There were indeed Byelorussian émigrés in Prague, but how could there have been any in Poland at that time, given that by the terms of the treaty of Riga Poland had occupied the western half of the country? The Hramada (Loftus insists on 'Gramada') was not a Polish organization (p.34) but a Byelorussian political party in Poland in the 1920 s. Linguistic ignorance or fundamental illiteracy leads to a confusion of the terms 'translation' and 'transliteration' on p.91. Loftus asserts that Byelorussians deliberately altered the spelling of their surnames to escape detection as war criminals, in blissful ignorance that these people in the course of their life had had to spell their names in at least four different ways, two in Cyrillic (Russian and Byelorussian) and two in Latin script (Byelorussian and Polish), e.g. Островский, Астроўскі, Astroǔski, Ostrowski. Since Loftus attaches so much importance to precise transliteration, it is amazing that he makes so many errors himself (or, to be fair, his helpers made them): 
who is Jury Bartishevic (p.51)? Nezvish is a very poor rendition of Нясвіж (Library of Congress rules would give Niasvizh) and Belovezh is hardly acceptable for Белавежа (unless we are dealing with the Russian form of the name, and there is no excuse for that since the place is not in Russia). The most ludicrous of these errors is the index entry on p.192 'Kushel, Arsenieva', thereby demonstrating that Loftus and his helpers cannot distinguish Christian names from surnames.

This sloppy approach to detail is extended to the form in which bibliographical information is provided in the notes, or indeed is not provided at all. A truly classic example of the way in which errors are passed on from one writer to another through a combination of ignorance and carelessness can be found in note 13 on p.164. The reference is to Eugen Engelhardt's Weißruthenien: Volk und Land, 1943 (the title is misspelt by Loftus and no page number is cited). Loftus seeks to demonstrate that 'over half of the persons' named by Engelhardt, eight in all, on p.215 of this book as 'leading representatives of the Byelorussian Union of University Students before World War II' became Nazi collaborators during the war. 'Over half' of eight is at least five. Of the persons listed, two (Čerepuk and Varonka) had been in the United States since the 1920s; one, Fr. Cikota, served in Rome as superiorgeneral of the Marian Fathers during the period 1933-39. At the expiry of his term of office in 1939 he could not return to Byelorussia because of the Soviet occupation. He went on missionary work to Manchuria and in 1948 was arrested by the communists. He died in a Soviet concentration camp in 1954. V. Zacharka, already a sick man when war broke out, died in Prague in March 1943 having consistently refused to have anything to do with the Nazi occupiers. Of the remaining four, only two, Abramčyk and Kasmovič are 'identified' by Loftus elsewhere in the book as 'collaborators'. Loftus 'identifies' Kasmovic with Zarečny. He is incorrect; Zarečny was the pseudonym of Ludvik Hałubovič, apparently a one-time officer in the NKVD. Loftus even repeats Engelhardt's mistake in giving Čerepuk's name as Cherepukan.

In the face of crimes so horrendous that they still defy the imagination, it may be held that all these points amount to no more than hairsplitting of a typically academic kind. However, it must be remembered that Loftus is claiming to have made discoveries that have escaped the attention of all other scholars of the Holocaust who have had access to the 'available public records', and is using his 'discoveries' to lay charges of war crimes against Byelorussians both living and dead. If his use of primary source material is sloppy and careless, so must his conclusions be. Indeed his central accusation is so breath-taking in its audacity as to be worth quoting in full: '. . the holocaust in Byelorussia was unique. In no other nation under German occupation did the inhabitants so willingly and enthusiastically visit such a degree oif inhumanity upon their neighbours' (p.29). To justify such a gross slander Loftus is forced to resort to tactical deviousness. The first such device is the sin of omission. N. Vakar's Belorussia: the making of a nation is referred to approvingly on p.121, since Vakar does indeed talk about 
Astroúski's role during the occupation. Loftus does not quote p.186 of Vakar's book, where he talks about the horrified reactions of Byelorussians to the mass killings of Jews. Wide use of the SS reports Ereignismeldungen and Tätigkeiten und Lageberichte has already been made to show the apathy of the Byelorussian population and their unwillingness to assist the Germans (see in particular the Yiddish-language Algemeyne entsiklopedie, Yidn, vol.6, New York, 1963, pp.259, $273 \mathrm{ff}$ ). Loftus uses Vakar in note 20 on p.167 to justify the remark on p.31 that 'the entire nation appeared to have defected to the Nazis', in complete contrast to Vakar's own point and to the line taken by every other researcher of the period, whether Soviet or western, Jewish or nonJewish. Loftus was unable to make use of the strongly anti-German (and anti-Soviet) Byelorussian underground publications such as the Biuleten Bietaruskaj Niezaležnickaj Partyi. Had he been able to do so, his view of the totally pro-Nazi stance taken by the Byelorussian people would have had to change.

A large question mark, therefore, hangs over Loftus' sources and the use he makes of them. His book abounds with illogicalities and unsupported statements. On p.22 we read that Kušal 'put together a fledgling police force' just after the occupation of Minsk in 1941, whereas on p.33 we are told that 'the Byelorussians had not even been permitted to form their own military organisation or national police force'. On p.44 we read of 'one of the ironies of history that the Poles, who had recently suffered so much at the hands of the Byelorussians, were first to give them shelter from the avenging Russians', after having learned from p.14 of the oppressive life under the Poles for Byelorussians in Poland between the wars. Given the activities of the Polish 'Armia Krajowa' in certain areas of Byelorussia during the war, one is entitled to ask who caused suffering to whom. In connection with these two illogicalities, it is instructive to point out Loftus' second sin of omission. He uses K. Akuła's Zmaharnyja darohi as evidence that Kušal was asked to form a police force in Minsk, but does not in the same context use Akuła's information about the role of the Poles in the police force formed by the occupiers. In a different context Loftus did not see fit to use Akuła as source material for the activities of the Belarus brigade; had he done so he would not have concocted the fantasy about the brigade fighting the Americans and then retreating to Germany after burying their dead at 'Biscenson' (this must be Loftus' version of Besançon). A little more care would not have put the 30th Waffen-SS division (der russische nr.2) at Monte Cassino; logistics and historical dates combine to confound Loftus on this point.

After the experiences of the Second World War the words 'collaborator' and 'collaboration' have acquired a decidedly negative flavour; Vidkun Quisling, by collaborating with the Germans in their occupation of his native Norway, gave a new and very nasty word to the English language. Alexander Werth, writing in the Manchester Guardian on 23 June 1941, applies the word to a very different context and shows a sad lack of historical understanding: 'Hitler may be relying on the 
emergence. . . of local Latvian or Estonian Quislings'. Let us face facts and ask a few direct questions. In September 1939 the Nazi-Soviet pact gave the USSR a free hand to unite Byelorussia within the Soviet state, and to increase its hold on the still independent Baltic republics until the inevitable occupation took place in 1940. Norway, on the other hand, led a perfectly normal independent existence until the Germans invaded in 1940, and its politicians could reasonably have been expected to resist the blandishments of power offered by them. What were the inhabitants of the previously independent Baltic states supposed to do? Should they have fought for a civil authority imposed upon them by force majeure, an authority which in any case vanished into thin air before the advancing Germans? The situation in Byelorussia is comparable in some respects: the country had been reunited under the terms of a treaty with Hitler; Soviet authority had not had time to strike deep roots in the west, and in the east (the pre-1939 BSSR) it had aroused considerable hostility. Given that the Germans regarded the war on the eastern front as a crusade against Bolshevism, and that there was a civilian population in the occupied area, it was obvious that anti-Bolshevik leaders should arise among the civilians, firstly to attempt to come to some kind of understanding with the occupiers and secondly to instil into Byelorussians an increased awareness of their national identity in order to obtain as much national independence as the situation allowed. The first of these tasks was common to all occupied countries, including the British Channel Islands, the second was unique to the USSR and arose directly from the tortured history of the area. Loftus talks blithely of a Byelorussian 'puppet government' serving the Nazis in the years 1941-43, but says nothing about its composition or powers. He ought to have been made aware that power was clearly vested in the German civilian authorities by the terms of para.4 of the order signed by Reichskommissar Lohse on 18 August 1941: 'Übernahme der Verwaltung durch den Reichskommissar für das Ostland'; the text appears in German and Byelorussian in Amtsblatt des Generalkommissars für Weißruthenien, 1, 30.9.1941, Minsk, pp.2-3. It is obvious that the Germans had Byelorussian assistants, but to talk of a 'puppet government' in the sense of Quisling's Norway or Vichy France is patently ridiculous. Loftus aims his most specific accusation, that of complicity in the massacre of Jews, against four Byelorussians, all of whom are now dead. By implication all other Byelorussians in USA, at least those in South River, New Jersey, must have to some extent been involved. The guilt would therefore seem to be presumed even while investigations are still being carried out. This in itself would seem to be a questionable procedure from the legal point of view but Loftus goes even further. The charge against Stanisłaù Stankievič of complicity in the massacre of the Barysaŭ ghetto in 1941 is not new and is not backed by any serious new evidence. If the Soviet authorities had evidence to back the charge, they have had ample opportunity to present it. In similar instances, evidence from the USSR has been accepted in American courts, and spoken of favourably by 
Allan Ryan, Loftus' chief at OSI. (See S. Karavanskij, 'Kto sledujuščij?', Kontinent, 36, 1983, pp.219-29, who advises caution.) The names of Byelorussian alleged war-criminals have been and continue to be given in the Soviet Byelorussian press (most recently in reviews of Loftus' book). Loftus accuses the Soviet authorities of being uncooperative in the cases against Byelorussians, in contrast to the cooperation received when dealing with Ukrainians or Lithuanians, because of the extensive Soviet spy network in the Byelorussian community in the USA which would of necessity be exposed if cases came to court. This amazing possibility begs a number of questions: why should the Soviet Union not have established spy networks among the numerically much larger Ukrainian community? Is Simon Wiesenthal involved? (After all he, of all men, is in a position to obtain evidence against Nazi war criminals and evaluate it, and Loftus' reference to him (p.138) is slighting, to put it mildly.)

Just a few more examples of Loftus' dubious methodology will suffice to call into question the reliability of the whole book. On p.74 Loftus writes 'Their [the Byelorussian 'collaborators'] claims to be leaders of a legitimate nationalist political movement were plainly without foundation, for, as the Manual [the Consolidated Orientation and Guidance Manual of the Counter-Intelligence Corps, issued in 1948] pointed out:

"To ease occupational problems and to take advantage of native nationalist feeling, the Germans created the puppet state of White Russia during their invasion. .."

If there was native nationalist feeling, why were Byelorussian nationalist leaders' claims without foundation? On p.91 we learn that 'most Belarus émigrés had already listed their birthplace as Polish Byelorussia to avoid the earlier repatriation efforts'. Might this not be because they had actually been born in 'Polish Byelorussia'? On p.107 Loftus casts doubt on the value of the research carried out by the Munichbased 'Institute of Russian Research'. Unfortunately there was no such body; there was an Institute for the Study of the USSR - yet another example of his sloppiness. A footnote on p.97 refers to an agent working in the Baltics (tantamount to saying that Loftus, when employed as a lawyer in Boston, worked in the Atlantics). Information on p.142 undermines the title of the book: "the library of Congress also contained sufficient information to sustain many of the Soviet charges against the Byelorussian collaborators'. Where is the secret, if the information has been published? The Byelorussians' real guilt, for Loftus, is in the fact that they wrote about themselves in their own language. Note also that here he writes about Soviet charges being made against Byelorussians, but on p.157 talkis about the Soviet government withholding evidence against them. (Some of the publications he 'discovered' are listed in note 40 on p.186, together with revealing misprints in the spelling of Byelorussian words.) Did Loftus, in his arrogant strivings to improve on the work of genuine historians like Hilberg, Reitlinger and Lucy Dawidowicz, never stop to think that Byelorussians have every right to use Byelorussian in their publications without considering the 
linguistic disabilities of a Boston lawyer, and that the very fact of publication - in whatever language - robs the events described of any veil of secrecy? In the wake of Klaus Barbie's extradition from Bolivia to France, the British edition adds little except a suitably sensational cover portraying the American flag with swastikas in place of stars. The only significant new information is contained on p.165 of this edition, where we learn that the Francis Ckrvyna (sic) Library in London is a private research group and had once housed Abramčyk's staff. Strange, since Abramčyk died in 1970, and the Francis Skaryna Library (assuming that this is what Loftus means) was founded in 1971. Abramčyk's portrait is also supposed to hang 'prominently in the lobby of the library'. As a regular user of the Library I can assure Loftus that it does not. Loftus describes the Library as possessing a complete set of Nazi propaganda papers published during the war; it unfortunately does not. It possesses runs of many newspapers and journals published in Soviet Byelorussia; does that make it a Soviet front organization as well?

Abramčyk later apparently moved to a non-existent street in Paris where he founded a 'similar "research" organization'. Similar to the Ckrvyna Library? If so, does anyone know where it is? The eager reader also discovers that Solomon Schiadow is still alive (excellent - perhaps he will authorize publication of his memoirs) and that Mrs Loftus has back trouble (I sympathize).

No-one can seriously maintain that Byelorussians could not possibly be implicated in Nazi war crimes. On the other hand, accusations, particularly when levelled against a whole nation, must be supported by evidence. It is clear that Loftus has not yet learned how to collect that evidence, and has insufficient linguistic and historical knowledge to deal with source material. 